\title{
Innovative Research on the Protection and Inheritance of Folk Cultural Heritage under the Background of Poverty Alleviation
}

\author{
Zhaozhen Song*, Jing Lu \\ Guangxi International Business Vocational College, Nanning 530007, Guangxi, China. \\ E-mail: 347644233@qq.com
}

\begin{abstract}
Chinese traditional culture is the root and soul of the Chinese nation, the soft power of the national culture, and the source to strengthen cultural confidence. As an important part of traditional Chinese culture, folk culture is the basis for telling Chinese stories well. Folk cultural heritage is the golden name card of national culture going to the world, and protecting and inheriting it is an important mission given by the new era. The important discussion on cultural heritage protection is not only a scientific inquiry into the practice of cultural heritage protection, but also points out the direction for cultural tourism to help poverty alleviation work.
\end{abstract}

Keywords: Cultural Heritage; Folk Culture; Poverty Alleviation; Protection and Inheritance

Traditional culture is not only the foundation of a nation's existence, but also the spiritual lifeline of a nation and country. Chinese traditional culture has a long history and has nourished generations of Chinese people without any faults. This is unique in the history of world civilization. Chinese traditional culture is not only a cultural concept, but also a spiritual symbol passed down from generation to generation in the Chinese nation. Inheriting and protecting cultural heritage is a sacred mission entrusted to us by history and nation. It also points out the direction for Guangxi cultural tourism to help poor areas get rid of poverty and become rich.

\section{The inheritance and development status of Guangxi folk culture}

Guangxi is located in the southern border of the motherland. It is the province with the largest number of ethnic minorities in China. It is home to 12 ethnic groups including Han, Zhuang, Yao, Miao, Dong, and Yi. In the long-term common life and social development process, various ethnic groups have created various forms and rich content of folk culture, such as singing folk songs and throwing hydrangea balls of the Zhuang people, playing bronze drums and group fish exercises of the Yao people, jumping reeds and climbing poles of the Miao people, the Dong nationality's firecrackers, the Jing nationality's Hajie, the Maonan nationality's Tongding and Tongpin; the Mulao nationality's elephant step and tiger palm, etc. These folklore cultures are important manifestations of folk customs, which are held in traditional festivals and agricultural slack seasons, and gradually formed a traditional culture of special festive food, weddings and funerals, and rituals. Tengfei Tu believes that folk culture is not only a sports culture, but also a life culture, as well as a collective, traditional, and life-oriented traditional folk culture inherited by the general public. The national and regional characteristics of folk culture attract a large number of travel enthusiasts and cultural researchers. The long and unique history and culture of ethnic minorities have continuously accumulated in the long river of history and become the intangible cultural heritage that shows the charm of the Chinese nation today. Folk culture, as intangible cultural heritage, is also non-renewable and irreplaceable, and must be protected, inherited, developed and innovated.

\section{Problems faced by the inheritance and development of Guangxi folk culture}

Copyright $\odot 2020$ Zhaozhen Song et al

doi: $10.18282 /$ le.v9i6.1291

This is an open-access article distributed under the terms of the Creative Commons Attribution Non-Commercial License

(http://creativecommons.org/licenses/by-nc/4.0/), which permits unrestricted non-commercial use, distribution, and reproduction in any medium, provided the original work is properly cited. 
As a multi-ethnic settlement, Guangxi not only has rich cultural and tourism resources, but also is a deeply impoverished area. The adjectives “old, young, border, mountainous, and poor” are used to summarize Guangxi's characteristic of poverty alleviation. In recent years, governments at all levels in Guangxi have responded actively to give full play to the advantages of cultural tourism and implement tourism poverty alleviation work. However, there are still some constraints.

First, the awareness of inheritance and protection is weak. Due to historical, political, economic, cultural and other factors, the development of Guangxi's folk culture and tourism is unbalanced. The integration of folk culture and tourism development in some poor areas has been well developed. However, due to excessive commercialization, the pursuit of profit value and relaxation of the bottom line consciousness. This led to the destruction of the local ecological and cultural environment, such as the Millennium Dong Village in Sanjiang Dong Autonomous County. In order to attract tourists and stimulate economic growth, Dong villages were transformed and upgraded. Due to the lack of scientific planning, effective implementation, and unified management measures, they used modern building materials, glamorous exterior wall coatings, and steel-framed house structures, which are incompatible with the Dong' thousand-yearold ethnic culture. It has lost the original ethnic architectural features and seriously affected the natural environment and visual effects of the Dong village.

Second, the development of tourism products is low and lacks national characteristics. The development of tourism projects is mainly based on ethnic gardens and ethnic cultural villages. The homogeneity in the village is serious. No matter which village you enter, you will see folk activities such as throwing hydrangea, walking shoes, and stepping on the Lusheng hall. No matter which scenic spot tourists visit, they can buy tourism products such as bamboo and wooden walking sticks, embroidered insoles, bracelets and beads, which can easily cause aesthetic fatigue and shopping boredom of tourists, and affect the travel experience. Some regions neglected to maintain the country flavor in the process of developing tourism projects. For example, the folk custom performances in scenic spots have obvious stage tendencies. Although the decorations are much more gorgeous than the real ones in life, they obviously lack The original charm of the decoration of this ethnic group. Ethnic villages lack the cultural characteristics of "one village, one feature", and the local customs have been severely weakened. It is difficult for such cultural tourism to inherit and develop in the long term, and it is difficult for tourism to help poverty alleviation.

Third, the lack of cultural and creative talents makes it difficult for a folk culture to be integrated into cultural tourism. The development of folk culture to help get rid of poverty and get rich requires careful planning. At present, there is a relative lack of cultural and creative talents in China, which restricts the development of cultural tourism to promote poverty alleviation and prosperity. For example, Guangxi's existing folk cultural tourism is mostly viewing-oriented, making tourists rush to different scenic spots one after one. At the same time, cultural and creative activities require time accumulation and practical proofs, it is difficult to reach a high level in a short time, and it is difficult to realize its own value. Therefore, there are fewer and fewer talents engaged in cultural creativity, especially young people.

\section{The way for the inheritance and development of Guangxi folk culture}

Folk cultural heritage is the commonwealth of the Chinese nation. It belongs not only to us, but also to the future generations. The protection and innovative development of folk culture is the central task of cultural heritage work in the new era. In order to get rid of poverty and become rich, the development of cultural tourism must not be for immediate benefit, disregarding the future, and then over-exploit and blindly use it. For folk culture, it is necessary to not only "keep it", but also "alive it" to inherit the folklore. The culture can "speak", tell the glorious stories passed down for thousands of years, and create a "golden business card" for folk culture to go out.

First, to promote the development of folk culture, it requires young people to inherit and love folk culture. First of all, under the impact of foreign culture, the loss of the mass base, and the lack of innovative talents, young people should become the main participants in folk cultural activities, willing to endure loneliness and poverty. The educated young people should form the awareness of protecting their own traditional culture, cherish their own culture, and consciously be the inheritors of folk culture. Second, it is needed to strengthen the talent training model of "school-enterprise cooperation and collaborative education". Universities in various places should become cultural and tourism develop- 
ment research bases, especially vocational colleges, to promote the combination of theory and practice, increase the required and optional courses related to folk culture, and dig deep into the core value to provide think tank support for folk culture tourism.

Second, use the "Internet +" technology to fully play the role of folk culture inheritance. One way is to introduce VR technology to allow tourists to fully experience folk cultural activities, such as the Binyang Fire Dragon Festival. On the one hand, tourists participate in the lively activities of the Fire Dragon Festival virtually, and on the other hand, the historical culture of the Fire Dragon Festival is reproduced in a panoramic view. The second is that tourism developers and cultural researchers can spread the folk culture of various ethnic groups in Guangxi through the official account or APP, so that people searching for Guangxi tourism strategy will not only know that there are Guilin landscapes and Beihai silver beaches, but also Songxu culture and ancient villages. Third, in terms of propaganda methods, such as the Hajie of the Jing nationality, Tongding of the Maonan nationality, and the Mulao nationality's folk cultural activities like stepping and tiger palms are limited to the audience. The platform live broadcast method can be used, and the live broadcast platform can be used for publicity and introduction.

Third, seize the opportunity of historical development and innovate the way of inheriting folk culture. Guangxi is one of the provinces with the most difficult task of poverty alleviation in the country. By the end of 2020, all poverty-stricken counties will be alleviated from poverty. Cultural tourism is used to promote poverty alleviation and promote economic development in impoverished areas. This is an important way to drive the poor out of poverty and become rich. In the process of promoting poverty alleviation, folk culture tourism must not only be well protected, but also must be innovated and inherited to adapt to the new tourism industry. For folk culture, it should play its economic role in poverty alleviation and agriculture, so that cultural tourism can be integrated with poverty alleviation and prosperity, and cultural tourism should be promoted with economic growth. For folk culture, it is necessary to expand its tourism function in precision poverty alleviation, to achieve the integration of protection and inheritance, and to be developed in a protective way.

\section{Conclusion}

Awe of history can create history, and not forgetting the original can open up the future. The key to poverty alleviation must be based on the strict protection of cultural heritage, effectively digging out the historical, scientific, and tourist values contained in folk culture, pinpointing the combination of history and reality, tracing the source, finding the root, finding the soul, and inspiring the majestic national self-confidence and cultural centripetal force. Cultural tourism should be a process of perceiving Chinese culture and enhancing cultural self-confidence and the means to drive economic development and help alleviate poverty. Cultural tourism should be regarded as a way to pursue a better and quality life.

\section{References}

1. Wang S, Cheng M. Research on the inheritance and innovation development of traditional sports intangible cultural heritage. Sports and Science 2020; 7(41): 1-6.

2. Tu C, Chen Z, et al. Analysis of the concepts and relationships of folk sports, traditional sports, folk sports, and national sports. Journal of Wuhan Institute of Physical Education 2007; 8(41): 24-31.

3. Hou L. Countermeasures to promote the development of tourism poverty alleviation in Guangxi under the background of targeted poverty alleviation. Reform and Strategy 2018; 4(34); 74-79. 